\title{
The Role of Trust in the Development of Web-based Customer Relationships
}

\author{
Carola Lange \\ University of Koblenz-Landau, Germany
}

\begin{abstract}
Maintaining individualized relationships to high-valued customers becomes more and more important in increasingly globalized and transparent markets. This paper discusses the concept of trust and its relevance for retaining customers in E-commerce. A model for buyerseller relationship development processes is applied showing that different stages of a relationship to a customer require different trustbuilding measures.
\end{abstract}

Keywords: customer relationships, CRM, eCRM, trust

\section{INTRODUCTION}

Due to the rapid technological progress and growing globalization of markets quality and price of competing goods and services are leveling more and more. Increasing availability of information has lead to more demanding customers (e.g. Picot et al., 2001). Particularly for businesses on the Web, discrimination can rarely be achieved through the competing products alone, but benefits extending the standard product are necessary.

It has been shown in different empirical studies that retaining customers is more profitable than acquiring more and more new customers, since the high cost of customer acquisition leads to unprofitable customer relationships in the beginning (see e.g. Hoffman/Novak, 2000, Bach/Österle, 2000, Reichhald/Schefter, 2001, Diller, 2001). Therefore, it is important for businesses to retain their profitable customers and maximize their customer's total life-time value.

Customer Relationship Management (CRM) is the main tool for building and maintaining individualized relationships to profitable customers through 
the proper usage of information and communication technologies (e.g. Wilde et al., 2001/1, Hippner et al., 2001). CRM has evolved to a buzzword used frequently in academic and business literature. Many companies claim to have developed and implemented a CRM strategy (May/Lister, 2001). However, there is more to CRM than just establishing a customer database and "amassing customer transaction data" (Harris, 1999). CRM as a process comprises monitoring the customer - i.e. collecting relevant customer data -, managing and evaluating the data, and finally actually taking advantage of extracted information in further customer interactions. Additionally, all business processes have to be re-aligned towards the customer; all customer touch points - such as marketing, sales, and service department - have to be represented consistently and coordinated towards the customer (Wilde et al., 2001/1).

In particular for establishing customer relationships on the Web, trust has been shown as a predominantly important concept (see e.g. Hoffman et al., 1999, Kundisch, 2001, McKnight/Chervany, 2001, Reichheld/Schefter, 2001). Viewing trust as the confidence to believe in the other party's reliability in the context of a buyer-seller relationship, its main function is to compensate the risks, which are in particular inherent in Internet transactions. The lack of face-to-face contact between buyers and sellers on the Internet requires new ways of representing a trustworthy and reliable company.

The types or functions of trust necessary in order to establish and further maintain a successful relationship to the customer differ depending on the stage a buyer-seller relationship is in. In the beginning, for example, an initial trust not based on experience, but based on a general attitude of confidence in the other party's favorable attributes or on a transfer of trust from a third (trusted) party is necessary (Ripperger, 1998, Egger, 2001). When a relationship has reached a stage where the customer is willing to reveal personal information and actual transactions take place trust based on direct experience should be fostered (Egger, 2001). This paper discusses the different aspects of trust and different trust building measures for the development of customer relationships.

Section 2 looks at customer relationship in further detail also discussing at the challenges arising for retaining profitable customers on the Internet. Section 3 gives a definition of the concept of trust from the view point of CRM. Referring to the model of the customer relationship development process introduced in Section 2.1 Section 3 discusses the different stages of the buyer-seller relationship in more detail. For each stage of a customer relationship the relevant aspects of trust are introduced and appropriate trustbuilding measures focusing on Web-based customer relationships are suggested. 


\section{CUSTOMER RELATIONSHIPS AND THE INTERNET}

The introduction showed that managing relationships to customers is necessary in order to retain profitable customers and in this way run a profitable business. The term customer relationship is used frequently in literature, but authors rarely give a definition of the term, generally assuming an implicit and intuitive understanding of it. The following subsection introduces a state-oriented view on buyer-seller relationships. Subsequently, implications of using the Internet as a channel for communication and interaction with the customer are discussed.

\subsection{Customer Relationships}

Two different views on the term customer relationship can be distinguished (Eggert, 2001). From the activity-oriented view point customer relationships are created through repeated exchanges (i.e. purchases) between the parties. A customer relationship exists, from the state-oriented point of view, if it is perceived to exist by both parties involved (Eggert, 2001). In this paper we will consider a state-oriented view of customer relationships (e.g. Dwyer et al., 1987), because we believe it is more flexible and reflects the nature of trust-based relationships. Accordingly, a customer relationship can take up different stages reflecting an increasingly closer relationship between buyer and seller.

Five separate phases of the relationship development process between a (prospective) buyer and seller can be identified (Dwyer et al., 1987): Awareness, Exploration, Expansion, Commitment, and Dissolution. These phases can be applied for analyzing traditional interactions in 'brick and mortar' industries and also for analyzing relationships between a prospective customer and a business represented on the Web using multiple channels of communication. Figure 1 depicts the development process, not visualizing the Dissolution ${ }^{1}$ phase and extended by the Transaction and After-Sales processes during the Commitment phase.

Each relationship to a customer requires both parties to initially become aware of each other (Awareness). After having become aware of a possible exchange partner a period of testing and evaluation can follow (Exploration), in which both parties consider possible costs and rewards of an exchange. Utilizing certain channels of communication the relationship can proceed to the next stage, the Expansion phase, in which both parties are willing to reveal personal information about their interests, because they have

\footnotetext{
${ }^{1}$ The final phase of a customer relationship will not be discussed in further detail, since the paper focuses on retaining (profitable).
} 
recognized an increase in benefits obtained by an exchange (Dwyer et al., 1987).

The actual transaction (purchase) takes place in the Commitment phase, in which the parties virtually preclude other possible exchange partners, who could provide similar benefits. Typically, transactions and after-sales services take place periodically during the Commitment phase. Further transactions (cross-/up-selling) might require additional processes of mutual evaluation and negotiation of conditions. However, we have placed them into the Commitment phase, since an already established relationship based on trust can be assumed.

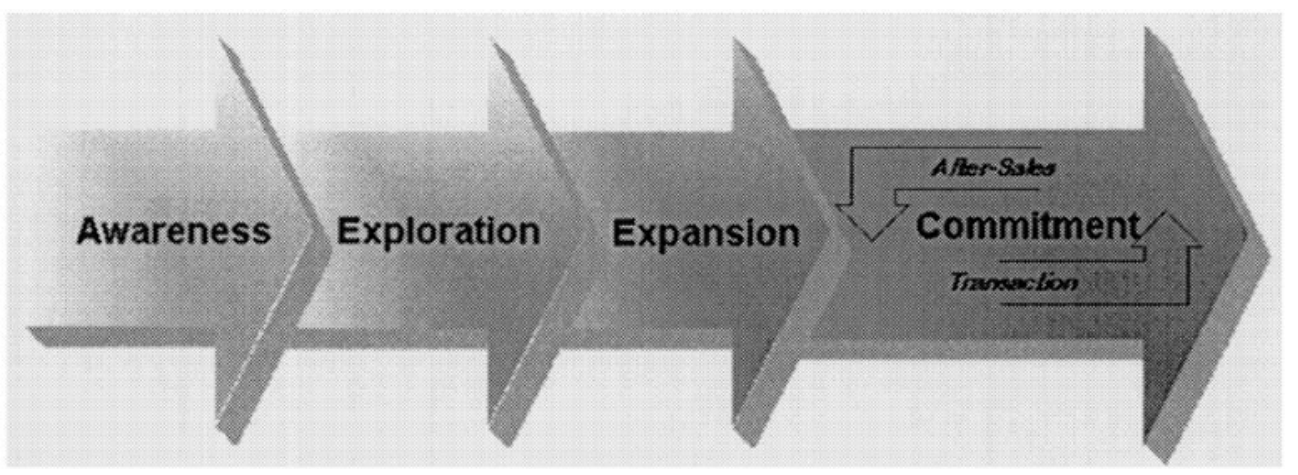

Figure 1. Stages of a Buyer-Seller Relationship

As opposed to other generally accepted models, which frequently view customer relationships more life cycle oriented, this model does not focus on single transactions (e.g.: gathering of information, bargaining, and purchase), but suits the idea of a (customer) relationship being based on trust and continuing over time, while purchases are made more or less frequently.

\subsection{Implications of the Internet}

The Internet - and the WWW in particular - has several well-known capabilities, which have a significant impact on customer relationships (see e.g. Bauer et al., 2000, Elberse et al., 2001):

- Fast and cheap information access.

- $24 \times 7$ availability (information availability independent of time).

- Seamless communication over any distance.

- Cheap and personalized interaction.

Fast and cheap information access leads to a higher market transparency. $24 \times 7$ availability and seamless communication over any distance makes the maintenance of long-term profitable customer relationships even more important for businesses represented on the Internet, since switching to another business does not require much effort from the customers side; the competing business is just 'a click away'. 
The profitability of customers in E-Commerce is similar to customer profitability in traditional ways of interaction. It has been shown in an empirical study for different E-Commerce sectors (entertainment electronics, books, groceries, clothing) that customers do not become profitable until after the first year of interaction with a certain business on the Web (Reichheld/Schefter, 2001).

While CRM focuses on maintaining profitable relationships to the customers through all (traditional) channels of communication, the term $e C R M$ is a new addition to the literature particularly taking into account the Internet as a vital channel of communication to the customer (see e.g. Wilde et al, 2001, Bauer et al., 2000/2).

There are many aspects relevant for traditional CRM, which are still valid when doing E-Commerce (eCRM). However, further opportunities and challenges for customer interaction and the maintenance of customer relationships arise (Reichheld/Schefter, 2001, Diller, 2001). One opportunity is the very cheap way of individualizing customer interaction through the World Wide Web and Internet technology. The more transparent markets and the competitor on the Web being just 'a click away' makes retaining profitable customers more challenging. The lack of face-to-face contact between buyers and sellers on the Internet requires new ways of representing a trustworthy and reliable company (Diller, 2001).

\section{THE CONCEPT OF TRUST}

In talking about building and maintaining customer relationships on the Web trust is predominantly important (see Section 1). A number of studies indicate that lack of trust is still one of the main factors for people hesitating to make transactions over the Internet (e.g. Ang et al., 2001, HarrisInteractive, 2002).

Providing economically risky input without an explicit contract or control mechanism together with the expectancy of the trusted partner not to behave opportunistic is typical for trust situations. Hence, trust relates to situations, in which the perceived risk depends on the behavior of another person (Ripperger, 1998). In the context of a buyer-seller relationship trust is considered as the belief of one party on the reliability of the other party and its willingness to fulfill his obligations in the exchange relationship (Dwyer et al., 1987, McKnight/Chervany, 2001).

Trust is a mechansim to compensate risks reducing the complexity of different action alternatives (Ripperger, 1998, Luhmann, 1973). The risk perceived by customers in particular in Web-based customer relationships has different dimensions (see e.g. Riemer/Totz, 2001, Ang et al., 2001, Cheskin, 2000): 
- Privacy: risk regarding the use (e.g. passing on) of personal information.

- Security: risk of the transaction not to be performed in a secure way, i.e. risk of third parties gaining or manipulating transaction data.

- Fulfillment: risk of the exchange partner not to deliver to his promises, i.e. risk of receiving the wrong or malfunctioning product.

- Reliability: risk of the exchange partner not to be willing to fulfill his commitments regarding after-sales and complain management, e.g. allowing money-back guarantee or returning of damaged goods.

A higher degree of uncertainty in buyer-seller interactions is a typical characteristic of E-Commerce as opposed to the traditional 'brick and mortar' buyer-seller interactions. Here the prospective buyer has been able to get an impression of the company through interaction with a sales representative and to actually see and test the product of interest. When purchasing products over the Internet the customer is not able to see and touch different product. He has to rely on photographs and promises from the seller-side, sometimes referred to as 'sell by description' (see e.g. Reichheld/Schefter, 2001). Hence, trust in the other parties good intentions is even more important in E-Commerce than in traditional buyer-seller interactions. Furthermore, trust implies willingness not based on having control over the other party, and the distance prevents customer control in ECommerce (McKnight/Chervany, 2001). This, again, emphasizes the importance of the concept of trust in Web-based customer relationships.

Dominating the online book market Amazon serves as a good example for an online company generally perceived as trustworthy. Because of Amazon's status of high credibility in terms of delivering the chosen products on time, millions of customers do not mind to give their name, address and credit card information (Reichheld/Schefter, 2001). However, the public reacted very conscious about usage of personal information, when Amazon proclaimed to change its privacy policy saying that Amazon could no longer guarantee that it would not disclose customer information to third parties. $^{2}$

\section{METHODS FOR INCREASING TRUST IN WEB- BASED CUSTOMER RELATIONSHIPS}

Different stages of a customer relationship imply different risks the customer perceives. Thus different aspects of trust and different measures for

\footnotetext{
${ }^{2}$ See for example http://www.epic.org/privacy/internet/amazon/letter.html, http://www.ecommercetimes.com/perl/story/4283.html.
} 
building trust are needed throughout the buyer-seller relationship development process.

Before the customer has made his own experience with a certain business, signaling measures to build trust need to be applied (Riemer/Totz, 2001). Sections 4.1 through 4.3 discuss which signaling measures for the establishment of trust in the early stages of a customer relationship are appropriate.

When a customer relationship has reached the stage, where actual transactions are performed, the business can foster the trust from customer side through actual fulfillment of promises made earlier. Indeed, trust can be build most effectively by proof of service (Albach, 1980, Riemer/Totz, 2001). However, in particular Web-based customer relationships require the customer to provide input (e.g. reveal personal data, give credit card information, and make payments) before proceeding to the stage where he can get a proof for the reliability and trustworthiness of the business (see Section 3). Section 4.4 discusses measures for building trust in the Commitment phase.

Figure 2 depicts the development process of customer relationships together with the trust-building measures in each stage. In the following subsections we introduce the different aspects of trust relevant in each stage and discuss various measures applicable for establishing and further maintaining customer relationships based on trust.

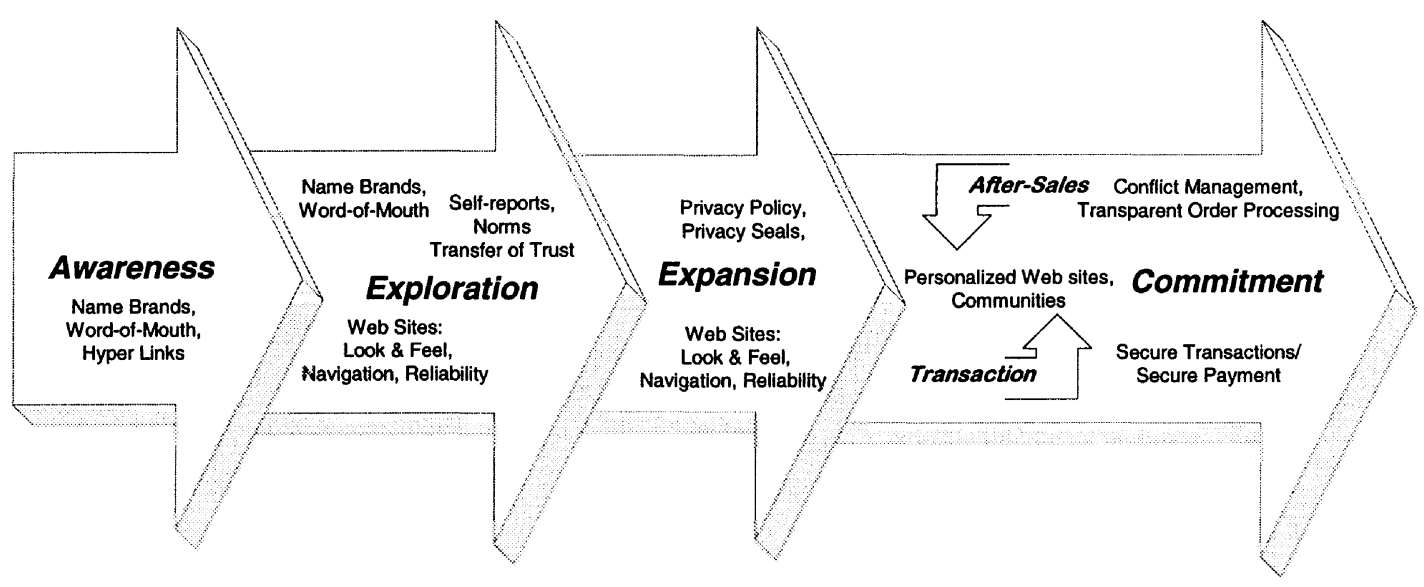

Figure 2. Trust building measures in the different stages of the customer relationship development process.

Even though the aspects of trust differ depending on the stage a customer relationship has achieved a general advice applicable to all stages can be given. Frequently, trust is built on the basis of experience and the influence of a certain experience grows with the perceived similarity of the current situation to the past experience (see e.g. Dwyer et al., 1987, Riemer/Klein, 
2001). Hence, measures for building trust should include adaptations of concepts familiar to the target customer from his 'brick and mortar' experience. Shopping carts as usually provided in online shops are a typical example for a familiar traditional concept applied. However, the degree of Web experience or technological background, which differs depending on the target customer segments, needs consideration (Riemer/Klein, 2001).

\subsection{Stage 1: Awareness}

Since every relationship requires the parties first to become aware of each other, the first phase of the buyer-seller relationship development process is called Awareness. It is usually the (prospective) buyer that starts to see or hear of the seller's business. Any possible actions to enhance one's attractiveness are still unilateral (Dwyer et al., 1987). Traditional marketing initiatives aim to create awareness among prospective customers through advertisements in mass media and developing strong name brands.

On the Internet, it is even more important to build corporate and product brand awareness, because there is so much competition for ,share of customer mind" (Kelly, 1999) that individual firms - particularly small ones - can find it very difficult to attract customers to their site to begin the customer relationship process. Since awareness has become the scarce resource some people even speak of the Attention Economy (see e.g. Zerdick et al., 2001).

However, the Internet also offers unique opportunities for catching the customers awareness. Targeted advertising in communities for example (see e.g. Schwabe, 2001) and tracking down of individual potential customers for direct marketing initiatives is possible using Web technologies. Additionally, Web technologies allow to "draw a direct line from advertisement to sale" (Hoffman/Novak, 2000) as opposed to traditional mass media, such as television, radio and newspapers, that do not allow to control the success of marketing initiatives.

Making prospective customers aware of your business requires measures that apply before a user has even accessed your Web site (see arrow „Awareness“ in Figure 2). In order for the company to be perceived as trustworthy from customer side, a trust transfer related to his own experience or the experience from a trusted third party has to be given (Ripperger, 1998). The trust transfer can stem from a well-known name brand, other trusted people communicating a positive experience (word-of-mouth), or well-known, trusted Web-Sites (e.g. of strategic partners) providing links to a company's Web site (e.g. Hoffman/Novak, 2000, Riemer/Klein, 2001). 


\subsection{Stage 2: Exploration}

The consecutive stage in the relationship between a customer and a business is characterized by considerations (in particular from the customer's side) about the suitability of the other party for an exchange. Hence, in this Exploration phase a company needs to present itself as trustworthy in terms of fulfilling the customers expectations. Here, again, benevolent word-ofmouth recommendation and a well-known name brand representing reliability can be applied as measures to enhance the perceived trustworthiness of a business (see arrow „Exploration“ in Figure 2).

A proper set of frequently asked questions (FAQs) accessible on its Web sites should be provided by a business on the Web in order to enable the interested customer to quickly decide if a further development of the relationship is beneficial from his point of view (Egger, 2001).

In order to allow the prospective customer to evaluate the advantages (rewards) and disadvantages (costs) of an exchange the business needs to make the relevant information easily accessible. As mentioned above, here, a challenge arises for businesses on the Web. In the traditional 'brick and mortar' buyer-seller interactions, the prospective buyer has been able to get an impression of the business, its reliability and trustworthiness by face-toface contact with a sales representative and being able to see the product of interest in a store-type environment. Neither a sales representative in person nor a physical store can be provided on the Web. Hence, new measures to build trust in a web-based buyer-seller relationship are necessary.

There are different trust-building measures replacing the role of a representative store environment. The Web site Look \& Feel has a significant impact on the first impression an Internet user gets from the respective business (Riemer/Klein, 2001). The layout needs to effectively convey the purpose of a Web site, i.e. it needs to represent clearly if the user can obtain information on a particular company or product, if he can purchase products, or if the customer can place customized orders over the Web (Cheskin, 2000).

A description of the company, its management, and employees (Self Reports) give the customer the opportunity to get a look inside the organization (Riemer/Klein, 2001). For example, pictures from employees put onto the Web sites would enable the customer to perceive to have a relationship with a group of people rather than with an impersonal company's Web site.

Web site navigation should be intuitive, easily leading the prospective customer to the information he is looking for. A reliable and sound functioning of the Web sites on application level is necessary to convey a competent and reliable image (Riemer/Klein, 2001).

Certain rules can replace uncertainties and compensate risks perceived by the customer (Albach, 1980). Norms for payment and shipping options, tax 
regulations, warranty, and after sales service should be made accessible to a prospective customer on the Web. For building trust proclaiming certain rules or norms cannot be equally effective as proof of service, but it helps the customers to trust in the benevolent intentions of a company. eBay is a good example for the successful establishing and controlling of norms for transactions performed on its platform. The risk for eBay users is reduced significantly by the obligatory assessment of buyer and seller after each transaction and the insurance eBay provides automatically for the first USD 200 of each transaction (Reichheld/Schefter, 2001).

Making relationships to other (from the customer's point of view) trusted organizations known to the prospective customers is another measure of building trust becoming relevant in the Exploration phase. The term Cause Related Marketing is used to describe agreements between a (for-profit) business and a cause or not for profit organization for mutual benefit ${ }^{3}$. The product of the for-profit company is expected to be associated with a social good and thus the attractiveness to a certain market segment which shares that perception and considers the non-profit organization as trustworthy is expected to increase (e.g. Goodwill, 1999).

\subsection{Stage 3: Expansion}

After having given the prospective customer the opportunity to get to know your company you want the customer to reveal personal information about himself in order to make further personalized interaction and a closer relationship possible. When collecting and analyzing user data aspects of privacy and customer data propagation become critical from the customers' point of view (see e.g. Wilde et al., 2001/1, Merzenich, 2001). The company has to represent itself as trustworthy and reliable in terms of dealing with personal data (see arrow „Expansion“ in Figure 2).

Making the privacy policy available is essential to enable the customer an assessment of the trustworthiness of a particular company (Hoffman et al., 1999, Riemer/Klein, 2001). A survey conducted by Harris Interactive showed that $75 \%$ of the US Americans surveyed consider it absolutely essential or very important for Web sites to display a notice and explain how their personal information will be used (BusinessWeek, 2000).

Usage of standard seals of approval can facilitate a transfer of trust. Different privacy seals, for example TRUSTe, VeriSign, ClickSure, assure the customer to have full control over the usage of personal information, (see e.g. Loebbecke/Hornig, 2001, Cheskin, 2000). The usage of privacy seals differs significantly between, the US Web sites and Web pages in other countries. According to Andersen Internet Privacy Survey $200145 \%$ of the

\footnotetext{
${ }^{3}$ According to Business in the Community, UK (http://www.bitc.org. uk/)
} 
US sites and merely $4 \%$ of the Australian sites use privacy seals (Andersen, 2001). Different empirical studies came to inconsistent results about the actual effectiveness of standard privacy seals.

Referring to a study performed in Europe, Riegelsberger and Sasse showed that a proper Web site Look \& Feel was more effective in terms of creating a trustworthy image than the usage of standard seals of approval (Riegelsberger/Sasse, 2001). Others argue that customers have not yet fully understood how privacy seals work, which would have led to their usage not being very effective (Cranor et al., 1999). A recent study performed by Harris Interactive indicates, that an independent verification of a companies privacy policy would satisfy $62 \%$ of the surveyed consumers in terms of making them trust companies to handle their personal information properly (HarrisInteractive, 2002). Hence, these results indicate that privacy seals can be effective, given the customers are aware of the way they work.

\subsection{Stage 4: Commitment}

When the customer has decided to perform an actual purchase the company has to present itself as trustworthy in terms of carrying out the transaction and reliable order fulfillment. A vital technology-based measure for the building of trust in the commitment phase is the visible usage of standard security and encryption technology (Karvonen et al., 2000, Riemer/Klein, 2001).

Providing the customer with a transparent service by giving him insights into order processing as well as giving him the opportunity to check the order status and track the different packages increases the obligation and credibility of the seller (Riemer/Klein, 2001, Egger, 2001, Cheskin, 2000).

An important instrument in the After-Sales phase is a proper conflict management; complaints and conflicts with exchange partners are more profitable than no communication at all (Dwyer et al., 1987, Riemer/Totz, 2001). Customer feedback should be taken seriously and managed reliably and obligingly. It can be valuable input for product improvement and is a significant factor for keeping dedicated customers. Here, AOL serves as a good example, since it performs conflict management in an exemplary way. Reasons for calls at the customer service center, for instance, are analyzed and insights from these analyses are used for the implementation of more intuitive and user-friendly interfaces of subsequent releases (Reichheld/Schefter, 2001).

A relationship based on trust is an important exit barrier, since a close trust-based customer relationship raises the psychological switching costs perceived by the customer. Emotionally affecting measures, such as personalized Web sites and establishing a customer community help to 
further raise these exit barriers (see e.g. Dwyer et al., 1987, Kundisch, 2001, Schwabe, 2001).

\section{CONCLUSION}

Increasingly globalized and transparent markets create the necessity for businesses to actively establish and manage individual relationships to their profitable customers. It has been shown that trust is an important concept, in particular, in the context of retaining customers on the Web, since customers perceive various (new) types of risks on the Internet (e.g. privacy, security, fulfillment). Hence, one of the major challenges arising through the usage of the Internet as an additional channel for communication and interaction is to find new ways of representing a trustworthy company.

Focusing on business-to-consumer relationships in E-Commerce, this paper discussed different aspects of trust and different trust-building measures applicable throughout the development process of Web-based customer relationship. As opposed to other generally accepted models, the model used in this paper focuses on customer relationships to a business, they are not related to a (single) transaction. This approach suites the idea of customer relationships being based on trust and continuing over time. The relationship does not start all over when a customer performs a new transaction. A basis of trust is still expected to be existing, mostly due to the customer's earlier experience in earlier transactions (if there had not been any trust damaging experience in the meantime (Riemer/Totz, 2001).

The relevance of trust for CRM has been emphasized earlier, in particular for the establishment of customer relationships on the Web. The model of customer relationships adopted in this paper helps to understand when to apply which of the many different trust-building measures. This can be seen as a starting point for researching the role of trust throughout a customer relationship process.

Future work questions need to address the actual effectiveness of the suggested trust building measures. Since the Internet allows to conduct business globally, further research can be done investigating the relevance of trust and different trust building measures in the light of cultural differences.

In order to further operationalize the suggested model, future work needs to address techniques for analyzing and reengineering E-Business mechanisms in terms of their contribution to managing customer relationships based on trust. 


\section{ACKNOWLEDGEMENTS}

The idea to write this paper originated in a student seminar at the University of Koblenz-Landau, Germany. I would like to give special thanks to Paula Swatman for valuable feedback on earlier drafts that significantly contributed to improve this paper.

\section{REFERENCES}

H. Albach: Vertrauen in der ökonomischen Theorie, In Zeitschrift für die gesamte Staatswissenschaft (ZgS) 136, p. 2-11, 1980.

Andersen Legal/Arthur Andersen Internet Privacy Survey 2001.

L. Ang, C. Dubelaar, B.-C. Lee: To Trust or Not to Trust? A Model of Internet Trust From the Customer's Point of View, in Proceedings of the 14th Bled Electronic Commerce Conference, Bled, Slovenia, 25-26 June 2001.

V. Bach, H. Österle (Hrsg): Customer Relationship Management in der Praxis - erfolgreiche Wege zu kundenzentrierten Lösungen, ISBN 3-540-67309-1, Springer Verlag BerlinHeidelberg 2000.

H. H. Bauer, M. Grether, M. Leach: Customer Relations Through The Internet, in: Ecommerce Research Forum, Volume 1, Issue 6, March 16, 2000.

H. H. Bauer, O. Göttgens, M. Grether: eCRM: Customer Relationship Management im Internet, in: Hermanns, A./Sauters, M. (2000): Management-Handbuch Electronic Commerce, 2. Auflage, Franz Vahlen Verlag München, München 2000, pages 119-131.

Business Week/Harris Poll: A growing Threat, in Business Week online, March 20, 2000.

Trust in the wired Americas, Cheskin Research, July 2000.

L. F. Cranor, J. Reagle, M. S. Ackermann: Beyond Concern: Understanding Net Users' Attitudes About Online Privacy, AT\&T Labs-Research Technical Report TR 99.4.3, April 1999.

H. Diller: Die Erfolgsaussichten des Beziehungsmarketing im Internet, in Eggert/Fassott, 2001, pp. 65-85, 2001.

Dwyer, F. Robert, Paul H. Schurr, Sejo Oh (1987), Developing Buyer-Seller Relationships, Journal of Marketing, 51 (April), 11-27.

F.N. Egger: Affective Design of E-Commerce User Interfaces: How to Maximise Perceived Trustworthiness. In: Helander, M., Khalid, H.M. \& Tham (Eds.), Proceedings of CAHD2001: Conference on Affective Human Factors Design, Singapore, June 27-29, 2001, pp. 317-324.

A. Eggert: Konzeptionelle Grundlagen des elektronischen Kundenbeziehungsmanagements, in Eggert/Fassott, 2001, pp. 87-106, 2001.

A. Eggert, G. Fassott (Hrsg.): eCRM - Electronic Customer Relationship Management: Management der Kundenbeziehungen im Internet-Zeitalter, Schäffer-Poeschl Verlag, Stuttgart, Mai 2001.

A. Elberse, K. Hammond, P. Barwise: Marketing and the Internet, Version 1.0, October 2001, London Business School, to be published in Weitz, Barton A \& Robin Wensley (Eds), Handbook of Marketing, Sage 2002.

C. Frielitz, H. Hippner, S. Martin, K. D. Wilde: $e C R M$ in der Praxis, in Wilde et al., 2001 pp. 81-89, 2001.

B. Goodwill: Cause Marketing Pros and Cons, October, 1999 Broadcast Café Newsletter. 
J. G. Harris: Finding the Customer in Transaction Data, Accenture, Institute for Strategic Change, December 1999. (www.accenture.com)

Privacy On and Off the Internet: What Consumers Want, Harris Interactive, February 19, 2002.

H. Hippner, S. Martin, K. D. Wilde: Customer Relationship Management, in WiSt, Heft 8, August 2001, pp. 417-422.

D. L. Hoffman, T. P. Novak, M. Peralta: Building Customer Trust Online, in Communications of the ACM (42:4), April 1999, pp. 80-85.

D. L. Hoffman, T. P. Novak: How to acquire customers on the Web, Harvard Business Review, May/June 2000, pp. 179-188.

K. Karvonen, L. Cardholm, S. Karlsson: Cultures of Trust: A Cross-Cultural Study on the Formation of Trust in an Electronic Environment, in Proceedings of the Fifth Nordic Workshop on Secure IT Systems, NordSec 2000, 12-13 October, 2000, Reykjavik, Iceland.

K. Kelly: New Rules for the New Economy, Penguin, USA, October 1999.

D. O. Kundisch: Building Trust - The Most Important CRM Strategy, Diskussionspapier WI100, Universität Augsburg, October 2001, accepted as paper for $3^{\text {rd }}$ World Congress on the Management of Electronic Commerce, Hamilton, Ontario, Canada, 2002.

C. Loebbecke, V. Hornig: Increasing Trust in e-Commerce: Concepts and Examples of Insurance Solutions, in Proceedings of $14^{\text {th }}$ International Electronic Commerce Conference, Bled, Slovenia, June 2001, pp. 1-18.

N. Luhmann: Vertrauen: ein Mechansimus zur Reduktion sozialer Komplexität, Ferdinand Enke Verlag, Stuttgart, $2^{\text {nd }}$ Edition, 1973.

C. May, R. Lister: Customer Relationship Management - Practice and preaching still far apart says Database Group Report, Lindsell Marketing Ltd.

D. H. McKnight, N. L. Chervany: Conceptualizing Trust: A Typology and E-Commerce Customer Relationships Model, in Proceedings of the $34^{\text {th }}$ Hawaii International Conference on System Science (HICSS 2001), IEEE.

M. Merzenich: Web Mining - Auf der Suche nach aussagekräftigen Daten, in Wilde et al, 2001 pp. 45-51, 2001.

A. Picot, R. Reichwald, R. T. Wigand: Die grenzenlose Unternehmung; Information, Organisation und Management, 4. rev. ed., Gabler, Wiesbaden, 2001.

F. F. Reihheld, P. Schefter: E-Loyalty: Your Secret Weapon on the Web, In Harvard Business Review, No 4, July/August 2000.

J. Riegelsberger, M. A. Sasse: Trustbuilders and Trustbusters: The Role of Trust Cues in Interfaces to e-Commerce Applications, In Proceedings of the 1st IFIP Conference on ecommerce, e-business, e-government (i3e), Zurich, October, 2001.

K. Riemer, S. Klein: E-Commerce erfordert Vertrauen, in WISU 5/01, pp. 710-717, 2001.

K. Riemer, C. Totz: Nachhaltige Kundenbindung im Internet, In M. Klietmann (Ed.): Kunden im E-Commerce, ISBN 3-93381455-3, Symposion, 2001.

T. Ripperger: Ökonomik des Vertrauens, Mohr Siebeck, 1998.

G. Schwabe: Communities, in WISU 02/2001.

K. D. Wilde, H. Hippner, C. Frielitz, S. Martin: Markstudie eCRM 2001 - Innovative Kundenbindung im Internet, absatzwirtschaft, Düsseldorf, 2001.

K. D. Wilde, H. Hippner, C. Frielitz, S. Martin: eCRM - Kundenbindung im Internet, in Wilde, 2001 pp. 9-36.

A. Zerdick, A. Picot et al.: Die Internet Ökonomie: Strategien für die digitale Wirtschaft, Springer, Berlin, 2001. 